Original Research Paper

\title{
Effect of Ecological Factors on Snails Infection by Schistosoma japonicum in Central Sulawesi, Indonesia
}

\author{
${ }^{1}$ Sutrisnawati Mardin, ${ }^{2}$ Teguh Wahju Sardjono, \\ ${ }^{2}$ Loeki Enggar Fitri, ${ }^{3}$ Aulanni'am and ${ }^{1}$ Achmad Ramadhan \\ ${ }^{I}$ Department of Biology, PMIPA FKIP Tadulako University, Central Sulawesi, Indonesia/Student as \\ Doctoral Program in Medical Science, Faculty of Medicine, Universitas Brawijaya, Malang, Indonesia \\ ${ }^{2}$ Department of Parasitology, Faculty of Medicine, Universitas Brawijaya, Malang, Indonesia \\ ${ }^{3}$ Laboratory of Biochemistry, Faculty of Science, Universitas Brawijaya Malang, Indonesia
}

\author{
Article history \\ Received: 27-11-2017 \\ Revised: 11-03-2018 \\ Accepted: 22-03-2018 \\ Corresponding Author: \\ Sutrisnawati Mardin \\ Department of Biology, PMIPA \\ FKIP Tadulako University, \\ Central Sulawesi, \\ Indonesia/Student as Doctoral \\ Program in Medical Science, \\ Faculty of Medicine, \\ Universitas Brawijaya, Malang, \\ Indonesia \\ Email: watikramadhan@yahoo.co.id
}

\begin{abstract}
In Central Sulawesi, Napu valley and Lindu Lake (Indonesia), Schistosoma are spread in the host snails (Oncomelania hupensis lindoensis). In the present work, the influence of ecological factors on the spreading of Schistosoma japonicum cercariae infection in the snails were analyzed. The Oncomelania hupensis lindoensis snails were collected and analyzed by ring method in the form of graphs and matrices. The results showed that, the ecological environment and such as temperature, $\mathrm{pH}$, humidity, light intensity, dissolved oxygen, and salinity, as well as food, have significant effect on the increase of cercariae infected snails. These results also reflect that Schistosomiasis is still a health problem that could potentially be re-emerging diseases, especially in those areas and therefore much interesting must considered to break their cycle in nature.
\end{abstract}

Keywords: Ecology, O.h. lindoensis, Cercariae S. japonicum

\section{Introduction}

Schistosomiasis is an infectious disease caused by several species of Schistosoma worms. It still being health problem in some certain endemic areas in Africa, as well as in America and Asia (Richards et al., 2006; Gryseels, 2012; Wu et al., 2005). The recorded infected persons were over 200 million around the world (Steinmann et al., 2006; Vidal et al., 2010).

Schistosoma japonicum is the most infection species around the Lindu Lake, Napu and Bada within the Valley of Central Sulawesi in Indonesia (Hadidjaja and Sudomo, 1976; Rosmini et al., 2014). Humans are the main or definitive host, while other mammals such as dog, pig and buffalo are serve as reservoir hosts as well (Sudomo and Pretty, 2007). Fresh water snail namely Oncomelania hupensis lindoensis is the intermediate host, where the worms continue their life cycle, starting from hatching of eggs in water then continued by penetration of miracidium into the body of snails until the production of cercariae (Hadidjaja and Sudomo, 1976). However, both humans and mammals are infected via penetration of the free swimming cercariae that come from the infected snails (Zhou et al., 2009).
Trials of the controlling of Schistosomiasis in Central Sulawesi has been done since 1974, through multisectoral approach, including the treatment of patients, snails eradication using moluscicide and agroengineering (Rosmini et al., 2014). The main target of those programs were to decrease the prevalence of Schistosomiasis to be less than 1\% (Rosmini et al., 2010) but up to date the prevalence of it is still fluctuative. The survey of snails during 2016 showed that, from 3560 collected snails in Lindu district, $\sim 53(1,50 \%)$ of snails were positive infected by cercariae of $S$. japonicum (Sutrisnawati et al., 2016). This ratio is higher than the former recorded ratio at 1,46\% (Sudomo and Pretty, 2007). The former work in the Napu region showed that, from $\sim 6874$ collected snails, $\sim 67(0.97 \%)$ snails were infected by cercariae (Sudomo and Pretty, 2007).

The persistence of cercariae $S$. japonicum infection in snails may be due to ecological conditions. Therefore, the present study is conducted to identify the predominant ecological factors or the effect of environment on the occurrence of cercariae infection of $S$. japonicum worms in snails in Lindu and Napu endemic areas. Such data can give idea for further work and try how we can break this cycle. 
In the present work, we focus on the ecological factors effect in the cercariae infection of S. japonicum worms in snails. These factors include mainly air temperature, water medium and its $\mathrm{pH}$ value, salinity, humidity and sunlight. We used advanced techniques in collecting the snails and statistical methods, Xlstat version 5.0. PCA and Statistical Product and Service Solutions (SPSS) version 2.0, in clarify the results. In the fact, these factors can give us an idea about how we can break this cycle in situ of its growing.

\section{Methods}

\section{Data}

In the present study, determination of the ecology of the habitats condition of O.h. lindoensis, comprise three analysis there were physical, chemical and biological factors in Central Sulawesi (include four villages in Lindu and another in Napu) (Fig. 1).

For ecologic determinations, collection of the samples, biologic condition, Principle Component Analysis (PCA) and the statistical analysis were our detailed studies.

\section{Snail Collection}

Based on a standard method of APHA (1998), snails were collected, from 12 stations (Fig. 2A), using the iron bracelet method (sized $\left.1 / 70 \mathrm{~m}^{2}\right)$. The iron bracelet was thrown in the snail's habitat and all the snails inside the bracelet were collected. After accumulation the samples, the snails were broken to collect snail-containing and the snail-free of cercariae $S$. japonicum inside the snail's body (Fig. 2B and 2C).

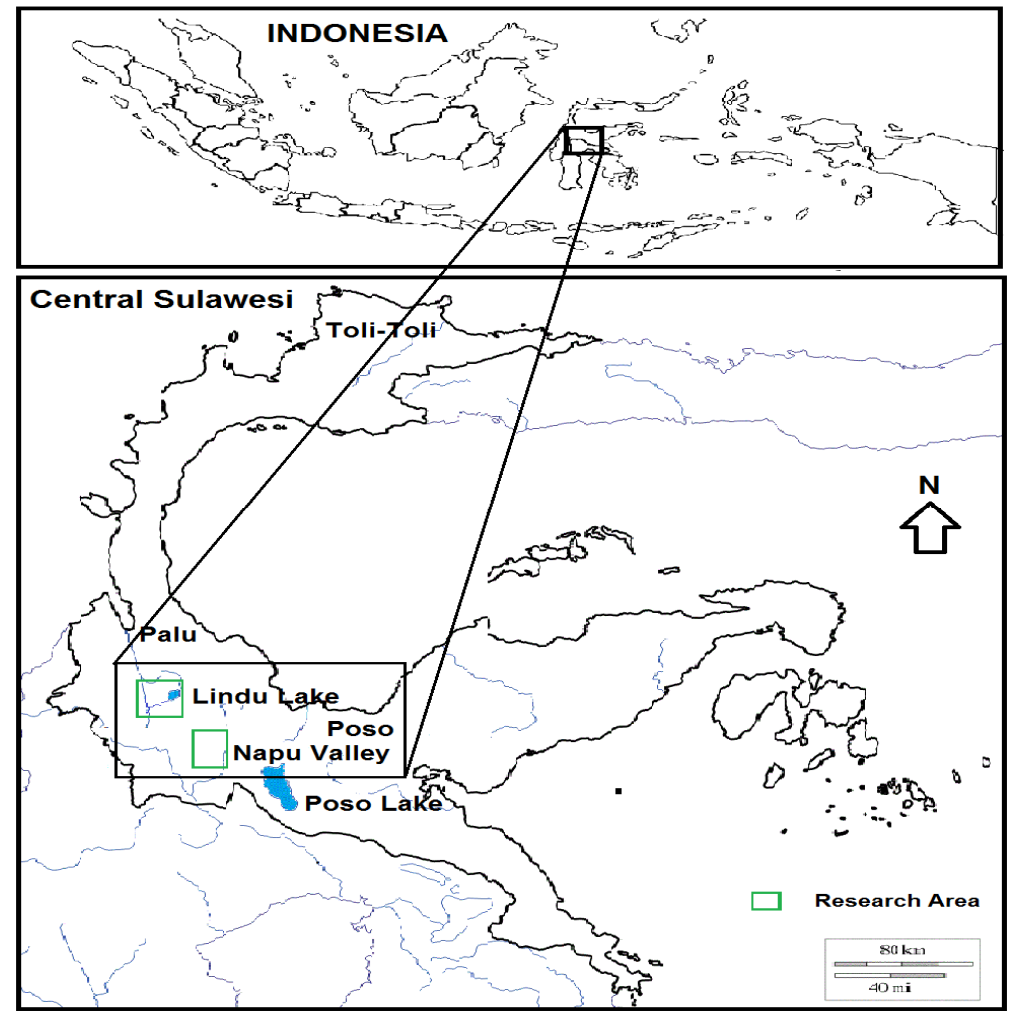

Fig. 1: The area of O.h. lindoensis snail collection in the region of Lindu and Napu, Central Sulawesi Province
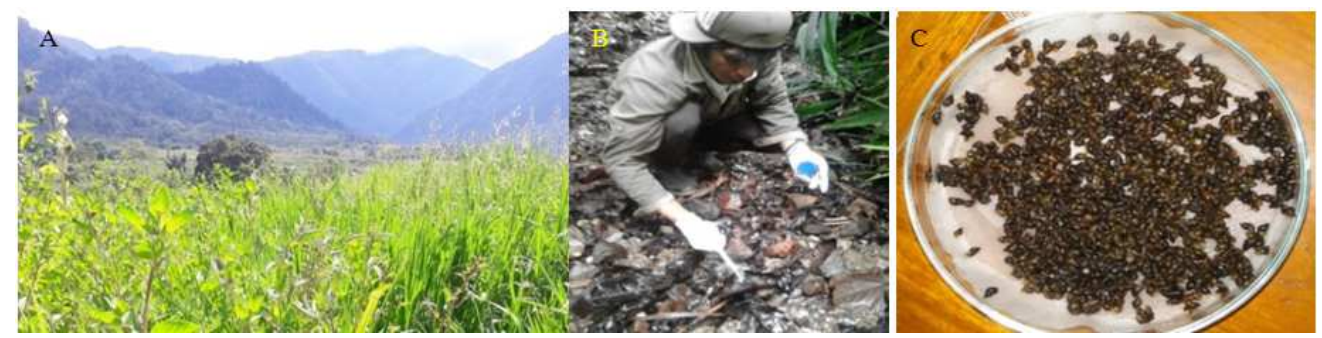

Fig. 2: Habitat and Snail Collection. A. One of O.h. lindoensis snail's habitat, B. Collection of O.h. lindoensis snail, C. Some of the O.h. lindoensis snails which were found 


\section{Data Analysis}

In the data analysis, Principal Components Analysis (PCA) was used for each factor using Xlstat version 5.0. PCA procedure. The later program is important in reducing the original independent variables that are correlated by using factor analysis. However, each factor of analysis represents the variables analyzed by the amount of variance called eigenvalue. Therefore, the first step was to determine the number of factors and the eigenvalue will show the variance of each of the main components.

According to the analysis of factors, criteria of eigenvalue greater than one was considered valid and being the number of factors formed (Umar, 2009). However if the total eigenvalue value was less than one, then the factor stated could not explain the variable well, therefore, it could not be included in the formation of variables (Abdi et al., 2013). We also used Statistical Product and Service Solutions (SPSS) version 2.0 (Campbell and Campbell, 2008) to know the effect of the ecology on the positive infected snails to know its prevalence.

\section{Results}

Prevalence of S. japonicum cercariae in O.h. lindoensis Snails in the Lindu and Napu

In this research, the number of O.h. lindoensis snail that infected with cercariae of $S$. japonicum found in the area Lindu was 133 from a total number of 7783 collected snails. The data showed that the average prevalence of snail infected by cercariae were $1.58 \%$. In Napu region the total number of snail that successfully collected were 3630 and the average prevalence of infected snail were $6.23 \%$ (Table 1 ).

In Lindu area; include villages of Tomado, Palili, Anca and Paku; the ratio of infected snails/ non-infected ones was 133/7783 whereas in Napu that were, include village of Sedoa, Mekarsari, Alitupu and Dololo, the ratio was 178/3630 (Table 1). Therefore, the average percentage of the infected snails in Lindu and Napu were
$3.90 \%$ and both Anca and (Lindu) Mekarsari (Napu) villages have the highest infected snails, by S. japonicum, of 2.34 and $18.61 \%$ respectively (Table 1) and Fig. 3.

\section{The Result of Ecology Determinant and Principal Component Analysis (PCA)}

The measurement of a biotic and biotic in the Lindu and Napu showed varying condition which can be seen in Table 2 and 3.

The Principle Component Analysis (PCA) in the Lindu area showed three factors have variance in total values (or Eigenvalue) greater than one, that include: 1. factors with eigenvalue 3.269 there were air temperature, humidity, water $\mathrm{pH}$ and dissolved oxygen (DO), 2. factors with eigenvalue 2.085 comprise water temperature, soil temperature and soil $\mathrm{pH}$ and 3. factors with eigenvalue 1.508 was salinity (Fig. 4A). In the other side, the PCA in Napu region, also showed three variance factors include: 1 . factors with eigenvalue of 4.856 comprise water temperature, soil temperature, air temperature, DO, light intensity, 2 . factors with eigenvalue value of 2.106 cover water $\mathrm{pH}$, soil $\mathrm{pH}$ and 3 . factor with eigenvalue of 0.941 only involved the salinity(Fig. 4B).

The aforementioned results of Principal Component Analysis method (PCA) showed that in Lindu region variability on first and second axes was $59.49 \%$ (Fig. 4A). This means that $59.49 \%$ of the analytical data can be explained up to the second major axis. The first and second component respectively describes $36.32 \%$ and 23.17 , respectively (Fig. 4A and $4 \mathrm{~B})$. In the Napu region the variability of F1, F2 was $77.35 \%$. Thus the result data analysis of $77.35 \%$ can be explained up to the second major axis (Fig. 5A and $5 \mathrm{~B})$. The first and second components explain $53.95 \%, 23.40 \%$ respectively (Fig. 5A and 5B).

Figure $5 \mathrm{~A}$ showed a correlation of physical and chemical environment parameter in the Lindu regional.

The results of multiple regression analysis were done to know the influence of the environmental ecology determinant $(\mathrm{X})$ on the increased of cercariae infected snail (Y) using software SPSS the results as follows (Table 4).

Table 1: The number of $S$. japonicum cercariae positive snails in several villages of Napu and Lindu

\begin{tabular}{llcrr}
\hline & & Number of snail & \\
Region & Village & Total & Positive & Prevalence (\%) \\
\hline Lindu & Tomado & 322.000 & 3.0 & 0.93 \\
& Palili & 3.345 & 52.0 & 1.55 \\
& Anca & 1.922 & 45.0 & 2.34 \\
& Paku & 2.194 & 33.0 & 1.50 \\
Number & 7.783 & 133.0 & 6.33 \\
Napu & Average & 1.945 & 33.0 & 1.58 \\
& Sedoa & 300.000 & 6.0 & 18.61 \\
& Mekarsari & 360.000 & 67.0 & 1.45 \\
& Alitupu & 550.000 & 101.0 & 4.17 \\
& Dodolo & 2.420 & 178.0 & 24.90 \\
\end{tabular}


Sutrisnawati Mardin et al. / American Journal of Environmental Sciences 2018, 14 (2): 55.62 DOI: 10.3844/ajessp.2018.55.62

Table 2: The characteristic of physical, chemical and biological environment in Lindu area

\begin{tabular}{|c|c|c|c|c|c|c|c|c|c|}
\hline \multirow[b]{2}{*}{ No } & \multirow[b]{2}{*}{ Ecology determinants } & \multicolumn{4}{|c|}{ Lindu area village } & \multicolumn{4}{|c|}{ Average and standard deviation } \\
\hline & & Tomado & Palili & Anca & Paku & Minimum & Maximum & Mean & SD \\
\hline 1 & Water temp $\left({ }^{\circ} \mathrm{C}\right)$ & 27.67 & 28.33 & 27.33 & 25.33 & 25 & 29 & 27.16 & 1.26 \\
\hline 2 & Soil temp $\left({ }^{\circ} \mathrm{C}\right)$ & 25 & 25 & 27 & 24 & 23 & 28 & 25.25 & 1.42 \\
\hline 3 & Air temp $\left({ }^{\circ} \mathrm{C}\right)$ & 28.33 & 27.67 & 24.67 & 24.33 & 23 & 29 & 26.25 & 2.09 \\
\hline 4 & Humidity (\%) & 82.33 & 82.67 & 91 & 86.67 & 80 & 92 & 85.66 & 3.93 \\
\hline 5 & Water $\mathrm{pH}$ & 7.3 & 7.53 & 6.9 & 7.23 & 6.7 & 7.8 & 7.24 & 0.31 \\
\hline 6 & Soil pH & 6.4 & 6,20 & 6,27 & 6.37 & 6 & 6.6 & 6.3 & 0.16 \\
\hline 7 & Salinity (\%o) & 0.53 & 0.57 & 0.5 & 0.53 & 0.4 & 0.7 & 0.53 & 0.08 \\
\hline 8 & DO $(\mathrm{Mg} / \mathrm{L})$ & 2.34 & 2.35 & 2.51 & 2.26 & 2.22 & 2.6 & 2.36 & 0.11 \\
\hline \multirow[t]{5}{*}{9} & Light intensity $(\mathrm{Cd})$ & 89 & 87 & 81.67 & 86.67 & 80 & 90 & 86.08 & 4.03 \\
\hline & Biological Factor & & & & & & & & \\
\hline & a. Chlorophycea & + & ++ & +++ & +++ & & & & \\
\hline & b. Diatomeae & ++ & + & ++ & +++ & & & & \\
\hline & c. Cyanophyceae & + & - & + & + & & & & \\
\hline
\end{tabular}

Table 3: The characteristic of physical, chemical and biological environment in Napu Area

\begin{tabular}{|c|c|c|c|c|c|c|c|c|c|}
\hline \multirow[b]{2}{*}{ No } & \multirow[b]{2}{*}{ Ecology determinants } & \multicolumn{4}{|c|}{ Napu area village } & \multicolumn{4}{|c|}{ Average and standard deviation } \\
\hline & & Sedoa & Mekarsari & Alitupu & Dodolo & Minimum & Maximum & Mean & SD \\
\hline 1 & Water temp $\left({ }^{\circ} \mathrm{C}\right)$ & 29 & 27 & 29 & 27.33 & 26 & 30 & 28.08 & 1.31 \\
\hline 2 & Soil temp $\left({ }^{\circ} \mathrm{C}\right)$ & 26.67 & 23 & 27.33 & 23.33 & 22 & 28 & 25.08 & 2.1 \\
\hline 3 & Air temp $\left({ }^{\circ} \mathrm{C}\right)$ & 29.67 & 25.67 & 30.33 & 23.67 & 23 & 31 & 27,33 & 2.93 \\
\hline 4 & Humidity (\%) & 80.67 & 81.67 & 85.33 & 88.67 & 80 & 89 & 84.08 & 3.37 \\
\hline 5 & Water $\mathrm{pH}$ & 6.9 & 7.27 & 7.2 & 6.57 & 6 & 7.4 & 6.98 & 0.41 \\
\hline 6 & Soil pH & 6.57 & 6.47 & 6.43 & 6.67 & 6.4 & 6.7 & 6.53 & 0.1 \\
\hline 7 & Salinity (\%o) & 0.67 & 0.53 & $0.43 *$ & 0.73 & 0.4 & 0.8 & 0.59 & 0.13 \\
\hline 8 & $\mathrm{DO}(\mathrm{Mg} / \mathrm{L})$ & 3.05 & 3.68 & 2.57 & 3.82 & 2.52 & 4.2 & 3.28 & 0.6 \\
\hline \multirow[t]{5}{*}{9} & Light intensity $(\mathrm{Cd})$ & 82.33 & 91.33 & 81.67 & 86.67 & 80 & 92 & 85.5 & 5.03 \\
\hline & Biological Factor & & & & & & & & \\
\hline & a. Chlorophycea & ++ & +++ & ++ & +++ & & & & \\
\hline & b. Diatomeae & + & +++ & ++ & +++ & & & & \\
\hline & c. Cyanophyceae & - & - & + & + & & & & \\
\hline
\end{tabular}

*At high sea level $(>1500 \mathrm{~m})$ and in heavy rainfall the water salinity may be lower and have un-normal value as in Alitupu village $(0.43 \mathrm{ppt})$
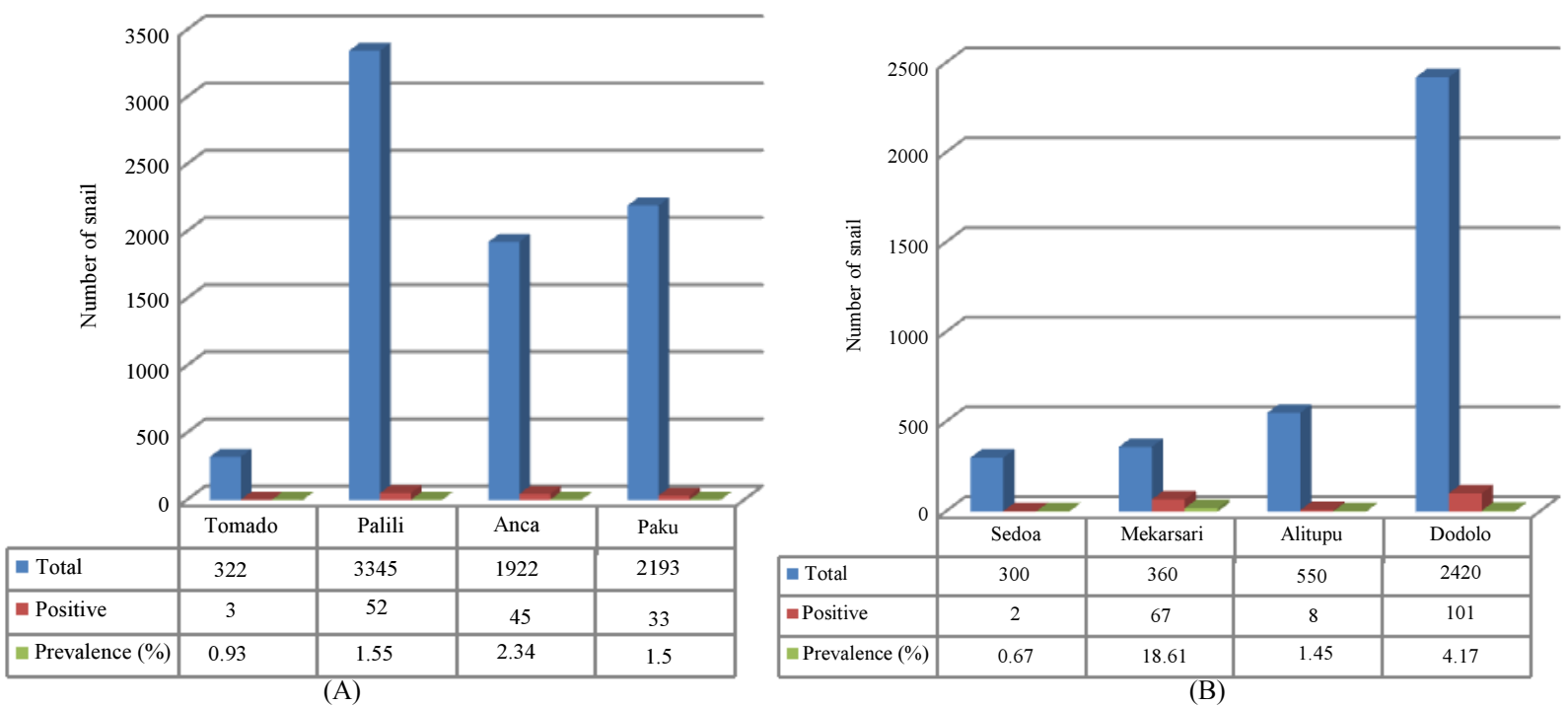

Fig. 3: The number of $S$. japonicum cercariae positive and prevalence snails in several villages of Lindu (A) and Napu (B) 


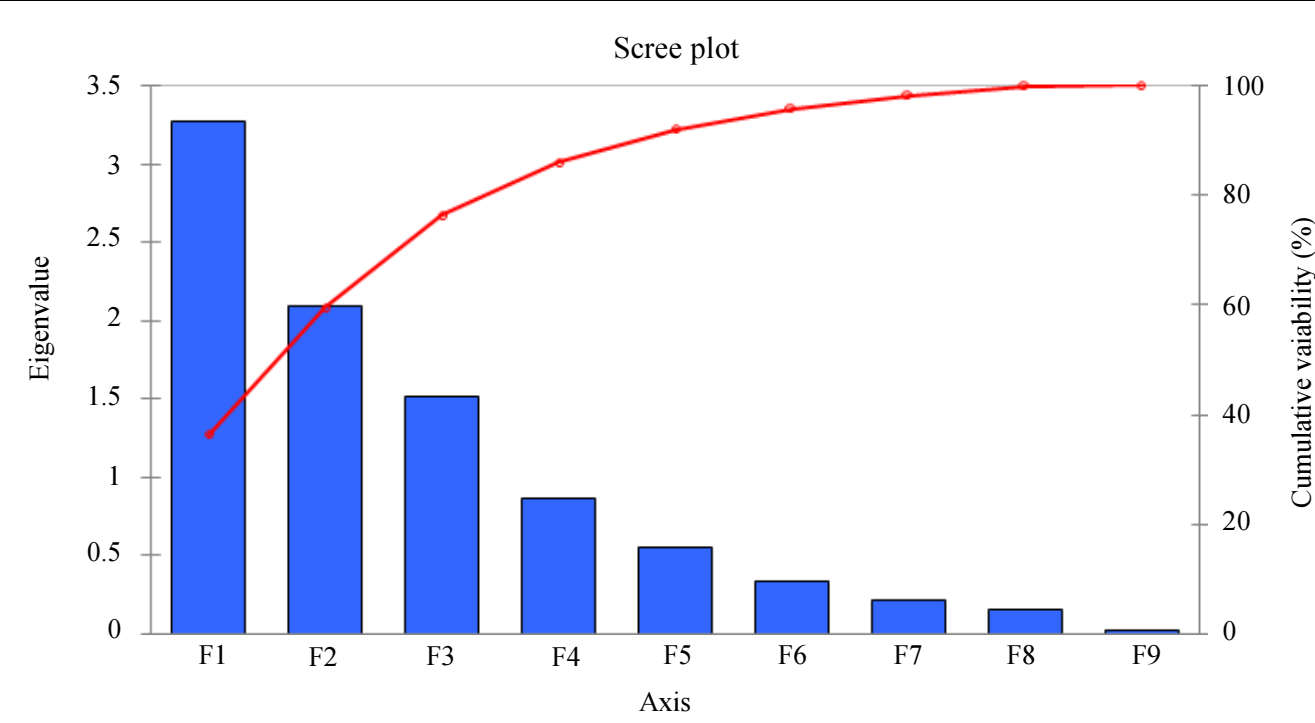

(A)

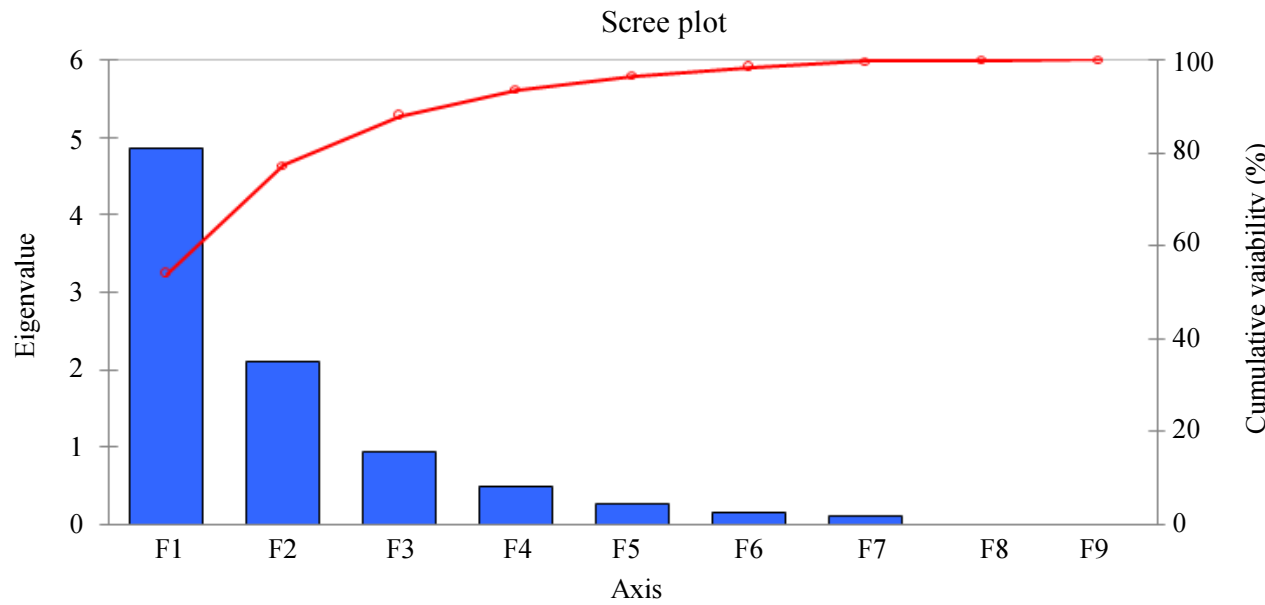

(B)

Fig. 4: Scree plot of the eigenvalue in the Lindu (A) and Napu (B)

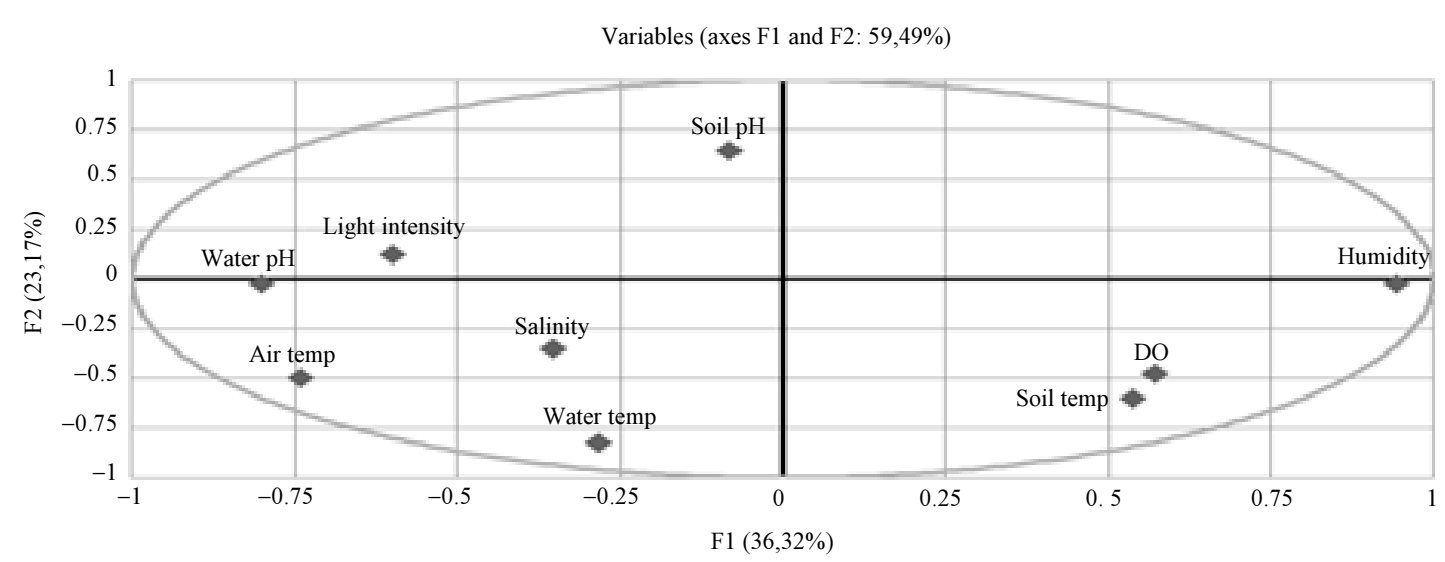

(A)

Biplot (axes F1 and F2: 59,49\%) 


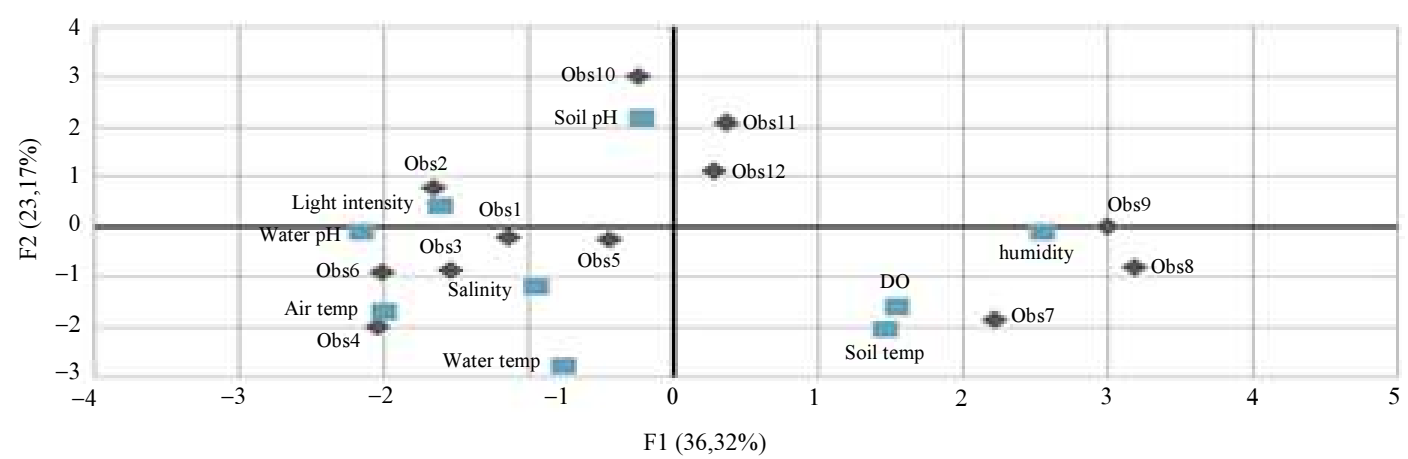

(B)

Fig. 5: A. Circle charts showed a correlation of physical and chemical environment parameter on an axis 1 and 2 based. B. Correlation between physical and chemical factors of the environment with observation stations in the Lindu regional.

Table 4: The influence of environmental ecology determinant on the increased of cercariae infected snail O.h. lindoensis in Lindu and Napu

\begin{tabular}{|c|c|c|c|c|c|c|}
\hline \multirow[b]{2}{*}{ Region } & \multirow[b]{2}{*}{$\mathrm{R}$} & \multirow[b]{2}{*}{ R square } & \multirow[b]{2}{*}{ Adjusted R square } & \multicolumn{3}{|l|}{ Change statistics } \\
\hline & & & & $\mathrm{R}$ square change & F change & Sig. F change \\
\hline Lindu & 0.953 & 0.909 & 0.827 & 0.909 & 11.085 & 0.000 \\
\hline Napu & 0.995 & 0.989 & 0.980 & 0.989 & 102.945 & 0.000 \\
\hline
\end{tabular}

The results of regression analysis revealed that environmental the ecology determinant was significantly influenced the increasing of cercariae infection on $O . h$. lindoensis snails in the Lindu and in the regions Napu $(p=0.00)$. The correlation between the determinants of environmental ecology and the increasing of cercariae infection in both regions is very strong, with looking to the correlation coefficient (R) of 0.95 and 0.99 (Table 4).

\section{Discussion}

The high rate of snail infection in both areas (Lindu and Napu) was caused by the ecology determinant. Both areas are in the height $>1500$ meter above the sea level and they always moist watery that allows a great distribution of water biota components as macro-fauna and micro-fauna which are suitable habitats condition for life of $O . h$. lindoensis snail. Habitats that highly favored by O.h. lindoensis snail is always muddy places throughout the year and are under shadow of the direct sunlight. Also, the traces of crops that has been left for a long time, the ruins of water channel that surrounding by thick and muddy grass-grown and the outskirts of the forest protected from sunlight that is always moist with water are highly favored for O.h. lindoensis snail (Sudomo and Pretty, 2007; Garjito et al., 2008). O.h. lindoensis snails were found scattered and improved in a great variety of habitats, such as rice fields, irrigation channels, river, a ditch and lake/pool (Rosmini et al., 2014). A kind of fresh-water gastropod that are shady and shielded more preferred by snails than habitats that are open this is due to many freshwater snails of the nature have negative phototaxis (Dillon, 2004). Actually the destroy of the snail regions was hard because it spread under mountains of hard topography habitation in the forest area.

In definitely, the results of physical and chemical parameters of the ecology in the Lindu region showed that humidity, air temperature, water $\mathrm{pH}$, were the most contributing factors in the increasing of cercariae $S$. japonicum infections on O.h. lindoensis snails. The results of this study in accordance with the results of previous research explains that humidity, temperature and climate, is a limiting factor on the presence of snails O.h. lindoensis (Zhou et al., 2012). Water temperature is considered to be one of the important aquatic environmental factors, especially in areas with slightly different seasons. The high temperatures concomitant with water can affect the development of the snail population (Fakult and Yang, 2006; David et al., 1987). It is known that $O . h$. lindoensis snails is an amphibian snail and its larvae need water for its life (Körner, 2007). When O.h. lindoensis snails grown into adulthood, slugs tend to live in moist areas (Fakult and Yang, 2006). The optimal temperature for the life of O.h. lindoensis snail between $16-28^{\circ} \mathrm{C}$ with a $\mathrm{pH}$ value of water between 6-8 (Rosmini et al., 2014). The later temperature is in accordance with the measurement results in our research. Previous studies have shown that the development of Schistosoma worms in snails as intermediate hosts is closely related to environmental temperature. The snails 
kept at $15.3^{\circ} \mathrm{C}, S$. japonicum arrested their development, while their fast development occurred at $30^{\circ} \mathrm{C}$ (Yang et al., 2007). High temperatures accelerate the development of the population of miracidia into cercariae in the body of a snails (Bavia et al., 1999). In the Lindu region (Anca village) the main factors causing increased cercariae infections in snails are temperature (comprise temperature of air, soil and water) and disolved oxygen. The second factor causing an increase in cercariae infection in snails is $\mathrm{pH}$ (water and soil) and salinity. Donnelly et al. (1984) suggests cercariae Schistosoma live in low salinity i.e., 0.52 in fresh water. At higher salinity gradually cercariae will die. In the Napu region (Mekarsari village) the temperature conditions (comprise temperature of air, soil and water) in addition to the disolved oxygen that support the breeding of snails. The ideal temperature conditions are caused by high rainfall that can adjust the suitable condition for development. Temperature and humidity are the fundamental environmental factors to encourage or limit the distribution and abundance of a biological organism (Bavia et al., 1999; Sulieman et al., 2013). The sun light is also the principal stimulus that causes emergence of both $S$. haematobium and S. mansoni cercariae, thus, shedding of cercariae may take place at water temperatures between 10 to $30^{\circ} \mathrm{C}$, or even at higher (Mouritsen, 2002).

The parameter of water biology that was observed was phytoplankton. Based on the identification of known phytoplankton, there were three classes of phytoplankton found in the waters of the research sites (Lindu and Napu Region) that comprise Chlorophycea, Diatomae and Cyanophycea. In our work, abundance of phytoplankton on the entire regions of collected snails showed that the class Chlorophycea is more dominant compared with other classes. However, other added that Diatomae class are the main food of O.h. lindoensis snails (Hadidjaja and Sudomo, 1976).

Based on R square value, the contribution of ecology determinant to infection of cercariae larvae at snail $O . h$. lindoensis at Lindu area was $90.9 \%$ and at Napu region was $98.9 \%$ (Table 4). The present study are in accordance with the previous research which explains that humidity, temperature and climate, are the limiting factors of the presence of O.h. lindoensis snails (Zhou et al., 2012). Really the environmental factors in any place not only include one factor, but usually various factors that mutually interact (David et al., 1987).

\section{Conclusion}

The results PCA and of regression analysis indicate that the determinant of the environmental ecology such as temperature, $\mathrm{pH}$, humidity, light intensity, dissolved oxygen, salinity, food, significantly affect the increase of cercariae infections in snails of O.h. lindoensis in the region of Lindu and Napu. These findings provide information that the determinant of environmental ecology was conducive to the survival of the snails and will also support the development of miracidium to be cercariae stage in the body of snails.

\section{Conflict of Interests}

All authors declare that they have no conflict of interests.

\section{Acknowledgment}

The authors thank to his Students for Supporting this Research.

\section{Author's Contributions}

Sutrisnawati Mardin: Participate in all research, conduct data analysis and contribute to the writing of the manuscript.

Teguh Wahju Sardjono, Loeki Enggar Fitri and Aulanni'am: Supervisor (Contribute to the preparation and editing of articles).

Achmad Ramadhan: Assisting in field research, taking ecological data and analyzing data.

\section{Ethics}

This article is original and independency of this research was highly ensured. There will be no issues of ethics following the publication of this article.

\section{References}

Abdi, H., L.J. Williams and D. Valentin, 2013. Multiple factor analysis: Principal component analysis for multitable and multiblock data sets. Wiley Interdisciplinary Rev.: Comput. Statist., 5: 149-179. DOI: $10.1002 /$ wics. 1246

APHA, 1998. Standard Methods for the Examination of Water and Wastewater. 20th Edn., American Public Health Association/American Water Works Association/Water Environment Federation, pp: 552.

Bavia, M.E., L.F. Hale, J.B. Malone, D.H. Braud and S.M. Shane, 1999. Geographic information systems and the environmental risk of schistosomiasis in Bahia, Brazil. Am. J. Trop. Med. Hyg., 60: 566-572. PMID: 10348229

Campbell, D. and S. Campbell, 2008. Statlab workshop introduction to regression and data analysis with. Analysis.

David, M.L., M.B. Kenneth, P.K. Steven, A.S. Roy and P.C. Alan, 1987. Distribution of freshwater snails: Spatial scale and the relative importance of physicochemical and biotic factors. Am. Malacol. Bull., 5: 73-84. 
Dillon, R.T., 2004. The Ecology of Freshwater Molluscs. 1st Edn., Cambridge University Press, United Kingdom, ISBN-10: 0-511-03715-5, pp: 523.

Donnelly, F.A., C. Appleton and C.H.J. Schutte, 1984. The influence of salinity on the cercariae of three species of schistosoma. Int. J. Parasitol., 14: 13-21. DOI: 10.1016/0020-7519(84)90005-5

Fakult, P. and G. Yang, 2006. Potential impact of climate change and water resources development on the epidemiology of schistosomiasis in China. $\mathrm{PhD}$ Thesis of Philosophy, University of Basel.

Garjito, T.A., M. Sudomo, A.M. Dahlan and A. Nurwidayati, 2008. Schistosomiasis in Indonesia: Past and present. Parasitol. Int., 57: 277-280. DOI: 10.1016/j.parint.2008.04.008

Gryseels, B., 2012. Schistosomiasis. Inf. Dis. Clin. North Am., 26: 383-397. DOI: 10.1016/j.idc.2012.03.004

Hadidjaja, P. and M. Sudomo, 1976. Some aspects on the ecology and biology of Oncomelania hupensis lindoensis. Southeast Asian J. Trop. Med. Public Health, 7: 227-232.

Körner, C., 2007. The use of altitude in ecological research. Trends Ecol. Evolut., 22: 569-574. DOI: $10.1016 /$ j.tree.2007.09.006

Mouritsen, K.N., 2002. The Hydrobia ulvae-Maritrema subdolum association: Influence of temperature, salinity, light, water-pressure and secondary host exudates on cercarial emergence and longevity. J. Helminthol., 76: 341-347. DOI: 10.1079/JOH2002136

Richards, F.O., A. Eigege, E.S. Miri, M.Y. Jinadu and D.R. Hopkins, 2006. Integration of mass drug administration programmes in Nigeria: The challenge of schistosomiasis. Bull. World Health Organizat., 84: 673-676. DOI: $10.2471 /$ BLT.06.029652

Rosmini, Soeyoko and S. Sumarni, 2010. Transmission of schistosomiasis in dodolo village and mekarsari highlands of Napu central Sulawesi. Media Litbang Kesehatan, 20: 113-117.

Rosmini, T.A. Garjito, A. Erlan and Gunawan, 2014. Infection rate intermediate host and Schistosoma japonicum reservoir prevalence in the highlands of Bada Central Sulawesi. J. Ekol. Kesehat, 13: 43-49.
Steinmann, P., J. Keiser, R. Bos, M. Tanner and J. Utzinger, 2006. Schistosomiasis and water resources development: systematic review, meta-analysis and estimates of people at risk. Lancet, 6: 411-425. DOI: $10.1016 / \mathrm{S} 1473-3099(06) 70521-7$

Sudomo, M. and M.D.S. Pretty, 2007. Schistosomiasis Control in Indonesia. Bull. Penelitian Kesehatan, 35: 36-45.

Sulieman, Y., T. Pengsakul and Y. Guo, 2013. Development and effects of Schistosoma japonicum (trematoda) on its intermediate host, oncomelania hupensis (Gastropoda). Parasitol Iranian J. Japonicum, 8: 212-218.

Sutrisnawati, R., T.W. Sardjono, L.E. Fitri and Aulanni'am, 2016. Infection rate of Schistosoma japonicum larva on Oncomelania hupensis lindoensis snails in Lindu District, Central Sulawesi Province, Indonesia: A Prelemenary Study in 2016. Proceeding 7th Asian Congress of Tropical Medicine and Parasitology, (TMP'16), pp: 86-86.

Umar, H., 2009. Literature study Principal Component Analysis (PCA). J. Kesehat Masy, 3: 97-101.

Vidal, C.H.F., F.V. Gurgel, M.L.B. Ferreira and H.R.C.D. Azevedo-Filho, 2010. Epidemiological aspects in neuroschistosomiasis. Arquivos NeuroPsiquiatria, 68: 72-5.

Wu, Z.D., Z.Y. Lü and X.B. Yu, 2005. Development of a vaccine against Schistosoma japonicum in China: A review. Acta Trop., 96: 106-116. DOI: $10.1016 /$ j.actatropica.2005.08.005.

Yang, G., J. Utzinger and L. Sun, 2007. Effect of temperature on the development of Schistosoma japonicum within Oncomelania hupensis and hibernation of $O$. hupensis. 100: 695-700. DOI: 10.1007/s00436-006-0315-8

Zhou, Y., H. Zheng, Y. Chen, L. Zhang and K. Wang et al., 2009. The Schistosoma japonicum genome reveals features of host-parasite interplay. Nature, 460: 345-351. DOI: 10.1038 /nature08140

Zhou, Y., S. Liang and Q. Jiang, 2012. Factors impacting on progress towards elimination of transmission of schistosomiasis japonica in China. Parasites Vectors, 5: 9-12. DOI: 10.1186/1756-3305-5-275 